\title{
1. Introduction to entrepreneurial narcissism
}

\subsection{THE MYTH OF NARCISSUS}

Here the boy, exhausted by the efforts of hunting and the heat, came to lie down, attracted by the beauty of the place and the source, but while trying to calm the thirst, another thirst is born to him. Kidnapped in drinking from the image he sees reflected, falls in love with a chimera: a body that is only shadow. Astonished he stares at himself and without being able to take his eyes off it remains petrified as a statue carved in Paro marble. Lying on the ground, he contemplates those two stars that are his eyes, hair worthy of Bacchus, worthy even of Apollo, and smooth cheeks, ivory neck, the beauty of the mouth, the pink suffused on the snow-white, and all he admires is what makes him wonderful. Desires, ignoring him, himself, lover and loved object, while he craves, he craves, and at the same time he lights and burns. How many times he throws useless kisses at the fiction of the source! How many times does he dip his arms in water to throw them around the neck he sees and that is not grasped in the water! (Publio Ovidio Nasone, Metamorphoses)

Narcissism, whose common concept is represented by self-adoration, is a subject of long-standing human fascination. The myth of Narcissus is certainly the best known in Greek mythology. It is so famous that it has become a word in common use, indicating a distinct trait of an individual: the immeasurable love for oneself. The myth of Narcissus tells the story of a beautiful young man who loses his life by falling madly in love with his own reflection. Clearly, the popular view only touches the surface of a vast and complicated phenomenon. 
Narcissism has become a defining feature of the modern era: interest in the concept has captured the imagination of the public, media, and literature. In the 1970s, the American journalist Tom Wolfe coined the phrase "the 'me' decade" to describe a rise in the celebration of the self (Wolfe, 1976), and the American historian and social critic Christopher Lasch (1979) published The Culture of Narcissism, which explored the emergence of narcissistic entitlement and decadence. These popularized texts have been paralleled by a growing body of academic interest and empirical research, particularly in the fields of psychology, social science, and cultural studies. Within psychiatry, the concept of narcissism has evolved from early psychoanalytic theorizing to its official inclusion as a personality disorder in psychiatric nomenclature.

Havelock Ellis was the first theoretician to use the myth of Narcissus to describe narcissism as a clinical entity, in his description of states of intense autoerotism or preoccupation with one's own sexual body (Ellis, 1898). Psychoanalysts subsequently elaborated the construct of narcissism as a personality characteristic of vanity and self-love that is neither exclusively sexual nor confined to the realm of pathology, but a normal part of human development. Otto Rank (1911) wrote the first psychoanalytic paper focusing on narcissism, which was followed by the publication of Freud's now classic text On Narcissism (Freud, 1914 [1991]). These works highlighted the defensive function of narcissism in protecting the individual from feelings of low self-worth and self-esteem, as well as conceptualizing narcissism as a dimensional psychological state that ranges from normal to pathological, forerunning the ideas introduced by more contemporary personality trait theorists (Levy, Ellison, \& Reynoso, 2011).

\subsection{THE PERSONALITY OF THE ENTREPRENEUR}

Entrepreneurship is a process that affects economic growth, innovation, and employment; therefore, it is an important and widely researched topic in the field of management (Decker, Calo, \& Weer, 2012). Within this field, previous studies have explored the role of the entrepreneur by analyzing their personal characteristics (Korunka, Frank, Lueger, \& Mugler, 2003; Leonelli, Ceci, \& Masciarelli, 2016; Leonelli, Masciarelli, \& Fontana, 2019; Mathieu \& St-Jean, 2013), attitudes (Block, Sandner, 
\& Spiegel, 2013; Desimoni \& Leone, 2014; Leonelli et al., 2019), behaviors, and qualities (Gardiner \& Jackson, 2015; Hatak, Harms, \& Fink, 2015; Matzler, Bauer, \& Mooradian, 2015), and how these can lead to entrepreneurial success (Markman \& Baron, 2003; Rauch \& Frese, 2000, 2007).

In this book we will focus on the personality of the entrepreneur. Entrepreneurial personality helps to clarify why entrepreneurs act differently when facing similar situations, as well as the reason that some entrepreneurs are more successful than others (Leonelli et al., 2016; Nga \& Shamuganathan, 2010). An individual's personality defines the person and it tends not to change over time (Vitelli, 2014).

It has been shown that personality traits such as optimism, locus of control, self-esteem, conscientiousness, and narcissism are crucial to entrepreneurial achievement (Baum \& Locke, 2004; Cooper, Gimeno-Gascon, \& Woo, 1994; Kee \& Chye, 1993; Kickul \& Zaper, 2000). However, a comprehensive understanding of how entrepreneurial personality shapes small business outcomes remains elusive. Identifying whether and how the entrepreneurial personality affects small firms would be a major contribution to management science, and entrepreneurship research in particular. Describing entrepreneurial personality traits is essential to understanding the way small firms create value (Mitchell et al., 2002; Wales, Patel, \& Lumpkin, 2013; Wallace, Little, Hill, \& Ridge, 2010). In the case of small firms, entrepreneurs have a greater impact on firm strategy; in larger organizations, firm size can increase the distance between decision-maker personality and firm outcome (DeTienne, 2010). In larger firms, decision-makers are more likely to delegate decision authority (Graham, Harvey, \& Puri, 2015), and the presence of several hierarchical levels might mediate the effect of the decision-maker's personality on results.

In this book, we will analyze both the bright and the dark sides of entrepreneurial personality, with a focus on entrepreneurial narcissism. Among the many personality traits identified in the literature, we will explore the role of the so-called Big Five personality traits (i.e., openness to experience, conscientiousness, extraversion, agreeableness, and neuroticism), the locus of control (i.e., internal and external), and the Dark Triad (i.e., narcissism, Machiavellianism, and psychopathy). In our book, all these traits will be conceived of as personality dimensions without considering them in relation to their extreme manifestations, which can be seen as personality disorders. Following prior studies, those traits can be categorized as bright or dark (Resick, Whitman, Weingarden, \& 
Hiller, 2009; Smith, Hill, Wallace, Recendes, \& Judge, 2017). In general, bright traits are beneficial for individuals and firms, while dark traits are considered detrimental (Judge \& LePine, 2007). Bright traits include openness to experience - the tendency to be creative and perceptive; conscientiousness - being respectful of the rules and being organized; extraversion - the tendency to be outgoing, active, and enthusiastic; agreeableness - being kind, altruistic, and trusting (Zhao \& Seibert, 2006); and internal locus of control - the perception that personal attributes and behavior drive individual outcomes (Galvin, Randel, Collins, \& Johnson, 2018). Dark traits include narcissism - a sense of grandiosity, pride, egotism, and a lack of empathy (Chatterjee \& Hambrick, 2007); Machiavellianism - an individual tendency to be manipulative and achieve goals using any means; psychopathy - dysfunctional interpersonal behaviors of people who employ charm and manipulative techniques for personal gain (Paulhus \& Williams, 2002); neuroticism - the tendency to be anxious, fearful, and depressed (Zhao \& Seibert, 2006); and external locus of control - the belief in external forces affecting individual outcomes (Galvin et al., 2018).

Previous research demonstrates that both the bright and the dark traits of an entrepreneur's personality affect small firms in different ways, as well as affecting the recognition of business opportunities (Navis \& Ozbek, 2016), the exploitation of opportunities (Haynes, Hitt, \& Campbell, 2015; Ucbasaran, Westhead, Wright, \& Binks, 2003), and firm survival and growth (Ciavarella, Buchholtz, Riordan, Gatewood, \& Stokes, 2004; Grijalva \& Harms, 2014). Kickul and Gundry (2002) show that entrepreneurs with open personalities are more able to identify possibilities for developing new products and entering new markets. This personality trait facilitates firm growth and firm success through changes and transformations to organizational structures. Other authors show that extroversion and conscientiousness influence the ability to attract funding from angel investors (Murnieks, Sudek, \& Wiltbank, 2015), venture capitalists (Black, Burton, Wood, \& Zimbelman, 2010), and crowdfunding platforms (Bollaert, Leboeuf, \& Schwienbacher, 2019).

However, scholars have recently begun to challenge the conventional belief that bright traits are always beneficial and dark traits are always detrimental, thus exploring the potential upsides of dark traits as well as the potential downsides of bright traits (Smith et al., 2017). There is some evidence suggesting that the effects of different personalities on organizations are complex. For example, extreme levels of conscientiousness - usually considered a bright trait - can lead to failure to adapt 
to the context (e.g., Carter, Guan, Maples, Williamson, \& Miller, 2016; Judge \& LePine, 2007), while higher levels of narcissism - usually considered a dark trait - might be positive in certain situations (e.g., Castille, Buckner, \& Thoroughgood, 2018; Maccoby, 2003; Petrenko, Aime, Ridge, \& Hill, 2016).

Narcissism occupies a large part of the book. A narcissist is defined as an individual who is arrogant, overconfident, and self-important, who sees themselves as superior and deserving of special treatment, who requires admiration, lacks empathy, is authoritarian, tends to exploit others, and overestimates his or her abilities (Campbell, Goodie, \& Foster, 2004; Chatterjee \& Hambrick, 2007; Rosenthal \& Pittinsky, 2006; Wales et al., 2013). As stated above, the word narcissism has its origins in Greek mythology, and Freud (1914 [1991]) was the first to use the term "narcissist" to identify an individual manifesting self-admiration, self-promotion, and a tendency to see others as extensions of themselves (Chatterjee \& Hambrick, 2007). This implies both negative and positive aspects of narcissism. The positive aspects include the ability of narcissists to become leaders, support others, as well as contribute to social growth with innovative inputs (Maccoby, 2000). The negative aspects include a distorted view of self-worth, grandiosity, self-centeredness, arrogance, and exploitation of interpersonal relationships. Narcissists see others only as a means to satisfy their need for admiration and reinforcement (Campbell, Reeder, Sedikides, \& Elliot, 2000; Campbell, Rudich, \& Sedikides, 2002). The present book is focused on entrepreneur narcissism for three main reasons. First, previous studies show that narcissism is a personality trait common to those occupying leadership positions (Engelen, Neumann, \& Schmidt, 2016; Grijalva \& Harms, 2014). Second, it has been demonstrated that the strategic choices made by narcissistic individuals differ systematically from the choices made by non-narcissists (Chatterjee \& Hambrick, 2007). Third, within groups, narcissists tend to emerge as leaders and to be quickly perceived by others as effective and influential (Engelen et al., 2016; Judge, LePine, \& Rich, 2006).

\subsection{CASE STUDY: AN INTERVIEW WITH A NARCISSISTIC LEADER}

The personality and behavior of the leader, the perception that followers have of the leader, and the context where this interaction takes place are dynamics involved in the leadership process (McCallum \& 
O'Connell, 2009). Among the many other personality traits, narcissism is often linked to the personality of a leader; this is because it is easy to identify narcissists at the top of organizations, and partly because narcissism seems well-suited to leadership (Campbell \& Campbell, 2009). Leadership positions are a useful social platform for obtaining the narcissistic goals of self-enhancement and, on the other hand, sometimes followers are likely to see narcissistic personalities as leaders who need to be pleased (Deluga, 1997).

In the following, we recount an interview with a narcissistic leader, Luca Sassi (not his real name), a self-made entrepreneur who has successfully designed and implemented a pedagogic technique that stimulates the motor schemes coordinated by the brain to improve oral communication both in children and in adults. Luca Sassi proposes a treatment comprising three phases. The first requires an intensive therapy aimed at preventing the formation of the conditioned reflex of stuttering and the constitution of the word block. This phase is also designed to eliminate repetitions, prolongations, and interruptions. In the second phase, there is an intervention in the patient's behavioral psychology to eliminate performance anxiety, nervous tension, and to increase self-esteem and motivation. The last phase consists of a group therapy allowing a comparison among patients and an assessment of personal growth and the acquisition of motivation and confidence for social reintegration. For the purposes of the present study here is a part of our interview:

Interviewer: Please, can you explain what lies behind the success of your new technique?

Luca Sassi (LS): Unlike the conventional methods used by my peers, the new technique of treatment I devised consists of two integrated models: the first, that I can define technical, and the second, which is more psychological and impacts on cognitive and behavioral aspects. However, the most innovative factor is the relationship between the individual and me. Even the environment plays an important role, but the connection I establish with the individual is fundamental.

Interviewer: How do you put this new technique into practice? Do you have any colleagues or employees?

LS: For the success of my therapy, my figure is very, very relevant. The relationship I establish with the patient and my charisma make the individual trust me. I try to make him or her reflect in me to instill my motivation, my being. This reassures the patient and allows him or her to regain control of his or her life step by step. As for colleagues and workers, I can say that my collaborators are assistants. None of them can replace me, perhaps not because they are 
not able, but just because what I do is very peculiar ... the power of my words and gestures, my expert figure, the way I look in patients' eyes.

Interviewer: In the end, what are the results? Are your patients satisfied?

LS: The results are very positive, and my success is expanding. I operate in 30 Italian cities and many people have asked me to create a franchise based on my method. However, this is not possible because, even if my patients could attend the same course elsewhere, the results would not be the same since I would not be there.

This interview enables us to understand the importance of the leader and how his personality impacts on performance. Indeed, positive results depend on the fact that there is a leader with specific characteristics to advise and manage the business. We are faced with a narcissistic leader ... a successful narcissistic leader.

\section{REFERENCES}

Baum, J. R., \& Locke, E. A. (2004). The relationship of entrepreneurial traits, skill, and motivation to subsequent venture growth. Journal of Applied Psychology, 89(4), 587-598.

Black, E. L., Burton, F. G., Wood, D. A., \& Zimbelman, A. F. (2010). Entrepreneurial success: Differing perceptions of entrepreneurs and venture capitalists. The International Journal of Entrepreneurship and Innovation, 11(3), 189-198.

Block, J., Sandner, P., \& Spiegel, F. (2013). How do risk attitudes differ within the group of entrepreneurs? The role of motivation and procedural utility. Journal of Small Business Management, 53(1), 183-206.

Bollaert, H., Leboeuf, G., \& Schwienbacher, A. (2019). The narcissism of crowdfunding entrepreneurs. Small Business Economics, 1-20. Retrieved from https://doi.org/10.1007/s11187-019-00145-w

Campbell, W. K., \& Campbell, S. M. (2009). On the self-regulatory dynamics created by the peculiar benefits and costs of narcissism: A contextual reinforcement model and examination of leadership. Self and Identity, 8(2-3), 214-232.

Campbell, W. K., Goodie, A. S., \& Foster, J. D. (2004). Narcissism, confidence, and risk attitude. Journal of Behavioral Decision Making, 17(4), 297-311.

Campbell, W. K., Reeder, G. D., Sedikides, C., \& Elliot, A. J. (2000). Narcissism and comparative self-enhancement strategies. Journal of Research in Personality, 34(3), 329-347.

Campbell, W. K., Rudich, E. A., \& Sedikides, C. (2002). Narcissism, self-esteem, and the positivity of self-views: Two portraits of self-love. Personality and Social Psychology Bulletin, 28(3), 358-368.

Carter, N. T., Guan, L., Maples, J. L., Williamson, R. L., \& Miller, J. D. (2016). The downsides of extreme conscientiousness for psychological well-being: The role of obsessive compulsive tendencies. Journal of Personality, 84(4), $510-522$. 
Castille, C. M., Buckner, J. E., \& Thoroughgood, C. N. (2018). Prosocial citizens without a moral compass? Examining the relationship between Machiavellianism and unethical pro-organizational behavior. Journal of Business Ethics, 149(4), 1-37.

Chatterjee, A., \& Hambrick, D. C. (2007). It's all about me: Narcissistic chief executive officers and their effects on company strategy and performance. Administrative Science Quarterly, 52(3), 351-386.

Ciavarella, M. A., Buchholtz, A. K., Riordan, C. M., Gatewood, R. D., \& Stokes, G. S. (2004). The Big Five and venture survival: Is there a linkage? Journal of Business Venturing, 19(4), 465-483.

Cooper, A. C., Gimeno-Gascon, F. J., \& Woo, C. Y. (1994). Initial human and financial capital as predictors of new venture performance. Journal of Business Venturing, 9(5), 371-395.

Decker, W. H., Calo, T. J., \& Weer, C. H. (2012). Affiliation motivation and interest in entrepreneurial careers. Journal of Managerial Psychology, 27(3), 302-320.

Deluga, R. J. (1997). Relationship among American presidential charismatic leadership, narcissism, and rated performance. The Leadership Quarterly, 8(1), 49-65.

Desimoni, M., \& Leone, L. (2014). Openness to experience, honesty-humility and ideological attitudes: A fine-grained analysis. Personality and Individual Differences, 59, 116-119.

DeTienne, D. R. (2010). Entrepreneurial exit as a critical component of the entrepreneurial process: Theoretical development. Journal of Business Venturing, 25(2), 203-215.

Ellis, H. (1898). Auto-eroticism: A psychological study. Alienist and Neurologist, 19, 260-299.

Engelen, A., Neumann, C., \& Schmidt, S. (2016). Should entrepreneurially oriented firms have narcissistic CEOs? Journal of Management, 42(3), 698-721.

Freud, S. (1914 [1991]). On narcissism: An introduction. In J. Sandler, E. Spector Person, \& P. Fonagy (Eds.), Freud's “On narcissism: An introduction" (standard ed., pp. 3-32). New Haven, CT: Yale University Press.

Galvin, B. M., Randel, A. E., Collins, B. J., \& Johnson, R. E. (2018). Changing the focus of locus (of control): A targeted review of the locus of control literature and agenda for future research. Journal of Organizational Behavior, $39(7), 820-833$.

Gardiner, E., \& Jackson, C. J. (2015). Personality and learning processes underlying maverickism. Journal of Managerial Psychology, 30(6), 726-740.

Graham, J. R., Harvey, C. R., \& Puri, M. (2015). Capital allocation and delegation of decision-making authority within firms. Journal of Financial Economics, 115(3), 449-470.

Grijalva, E., \& Harms, P. D. (2014). Narcissism: An integrative synthesis and dominance complementarity model. The Academy of Management Perspectives, 28(2), 108-127.

Hatak, I., Harms, R., \& Fink, M. (2015). Age, job identification, and entrepreneurial intention. Journal of Managerial Psychology, 30(1), 38-53. 
Haynes, K. T., Hitt, M. A., \& Campbell, J. T. (2015). The dark side of leadership: Towards a mid-range theory of hubris and greed in entrepreneurial contexts. Journal of Management Studies, 52(4), 479-505.

Judge, T. A., \& LePine, J. A. (2007). The bright and dark sides of personality: Implications for personnel selection in individual and team contexts. In J. Legan-Fox \& R. J. Klimoski (Eds.), Research companion to the dysfunctional workplace: Management challenges and symptoms (pp. 332-355). Cheltenham, UK and Northampton, MA, USA: Edward Elgar Publishing.

Judge, T. A., LePine, J. A., \& Rich, B. L. (2006). Loving yourself abundantly: Relationship of the narcissistic personality to self- and other perceptions of workplace deviance, leadership, and task and contextual performance. Journal of Applied Psychology, 91(4), 762-776.

Kee, C. K., \& Chye, K. H. (1993). Personality characteristics of entrepreneurs: A test on the locals at the Singapore International Monetary Exchange. Journal of Small Business \& Entrepreneurship, 10(3), 59-68.

Kickul, J., \& Gundry, L. (2002). Prospecting for strategic advantage: The proactive entrepreneurial personality and small firm innovation. Journal of Small Business Management, 40(2), 85-97.

Kickul, J., \& Zaper, J. A. (2000). Untying the knot: Do personal and organizational determinants influence entrepreneurial intentions? Journal of Small Business \& Entrepreneurship, 15(3), 57-77.

Korunka, C., Frank, H., Lueger, M., \& Mugler, J. (2003). The entrepreneurial personality in the context of resources, environment, and the startup process: Configurational approach. Entrepreneurship Theory and Practice, 28(1), $23-42$.

Lasch, C. (1979). The culture of narcissism: American life in an age of diminishing expectations. New York, NY: Warner Books.

Leonelli, S., Ceci, F., \& Masciarelli, F. (2016). The importance of entrepreneurs' traits in explaining start-ups' innovativeness. Sinergie: Italian Journal of Management, 34(101), 71-85.

Leonelli, S., Masciarelli, F., \& Fontana, F. (2019). The impact of personality traits and abilities on entrepreneurial orientation in SMEs. Journal of Small Business \& Entrepreneurship. Retrieved from https://doi.org/10.1080/ 08276331.2019.1666339

Levy, K. N., Ellison, W. D., \& Reynoso, J. S. (2011). A historical review of narcissism and narcissistic personality. In W. K. Campbell \& J. D. Miller (Eds.), The handbook of narcissism and narcissistic personality disorder: Theoretical approaches, empirical findings, and treatments (pp. 3-13). Hoboken, NJ: John Wiley \& Sons, Inc.

Maccoby, M. (2000). Narcissistic leaders: The incredible pros, the inevitable cons. Harvard Business Review, 78(1), 68-78.

Maccoby, M. (2003). The productive narcissist: The promise and peril of visionary leadership. New York, NY: Broadway Books.

Markman, G. D., \& Baron, R. A. (2003). Person-entrepreneurship fit: Why some people are more successful as entrepreneurs than others. Human Resource Management Review, 13(2), 281-301. 
Mathieu, C., \& St-Jean, É. (2013). Entrepreneurial personality: The role of narcissism. Personality and Individual Differences, 55(5), 527-531.

Matzler, K., Bauer, F. A., \& Mooradian, T. A. (2015). Self-esteem and transformational leadership. Journal of Managerial Psychology, 30(7), 815-831.

McCallum, S., \& O’Connell, D. (2009). Social capital and leadership development: Building stronger leadership through enhanced relational skills. Leadership \& Organization Development Journal, 30(2), 152-166.

Mitchell, R. K., Busenitz, L., Lant, T., McDougall, P. P., Morse, E. A., \& Smith, J. B. (2002). Toward a theory of entrepreneurial cognition: Rethinking the people side of entrepreneurship research. Entrepreneurship Theory and Practice, 27(2), 93-104.

Murnieks, C. Y., Sudek, R., \& Wiltbank, R. (2015). The role of personality in angel investing. The International Journal of Entrepreneurship and Innovation, 16(1), 19-31.

Navis, C., \& Ozbek, O. V. (2016). The right people in the wrong places: The paradox of entrepreneurial entry and successful opportunity realization. Academy of Management Review, 41(1), 109-129.

Nga, J. K. H., \& Shamuganathan, G. (2010). The influence of personality traits and demographic factors on social entrepreneurship start up intentions. Journal of Business Ethics, 95(2), 259-282.

Paulhus, D. L., \& Williams, K. M. (2002). The Dark Triad of personality: Narcissism, Machiavellianism, and psychopathy. Journal of Research in Personality, 36(6), 556-563.

Petrenko, O. V., Aime, F., Ridge, J., \& Hill, A. (2016). Corporate social responsibility or CEO narcissism? CSR motivations and organizational performance. Strategic Management Journal, 37(2), 262-279.

Rank, O. (1911). Ein Beitrag zum Narzissismus [A contribution to narcissism]. In E. Bleuler \& S. Freud (Eds.), Jahrbuch für Psychoanalytische und Psychopathologische Forschungen (Vol. 3, pp. 410-423). Leipzig/Vienna: Franz Deuticke.

Rauch, A., \& Frese, M. (2000). Psychological approaches to entrepreneurial success: A general model and an overview of findings. International Review of Industrial and Organizational Psychology, 15, 101-142.

Rauch, A., \& Frese, M. (2007). Let's put the person back into entrepreneurship research: A meta-analysis on the relationship between business owners' personality traits, business creation, and success. European Journal of Work and Organizational Psychology, 16(4), 353-385.

Resick, C. J., Whitman, D. S., Weingarden, S. M., \& Hiller, N. J. (2009). The bright-side and the dark-side of CEO personality: Examining core self-evaluations, narcissism, transformational leadership, and strategic influence. Journal of Applied Psychology, 94(6), 1365-1381.

Rosenthal, S. A., \& Pittinsky, T. L. (2006). Narcissistic leadership. The Leadership Quarterly, 17(6), 617-633.

Smith, M. B., Hill, A. D., Wallace, J. C., Recendes, T., \& Judge, T. A. (2017). Upsides to dark and downsides to bright personality: A multidomain review and future research agenda. Journal of Management, 44(1), 191-217. 
Ucbasaran, D., Westhead, P., Wright, M., \& Binks, M. (2003). Does entrepreneurial experience influence opportunity identification? The Journal of Private Equity, 7(1), 7-14.

Vitelli, R. (2014). The everything guide to overcoming PTSD: Simple, effective techniques for healing and recovery. Avon, MA: Adams Media Corporation.

Wales, W. J., Patel, P. C., \& Lumpkin, G. T. (2013). In pursuit of greatness: CEO narcissism, entrepreneurial orientation, and firm performance variance. Journal of Management Studies, 50(6), 1041-1069.

Wallace, J. C., Little, L. M., Hill, A. D., \& Ridge, J. W. (2010). CEO regulatory foci, environmental dynamism, and small firm performance. Journal of Small Business Management, 48(4), 580-604.

Wolfe, M. T. (1976 [2008, April 8]). The "me" decade and the third great awakening. New York Magazine. Retrieved from https://nymag.com/news/features/ 45938/

Zhao, H., \& Seibert, S. E. (2006). The Big Five personality dimensions and entrepreneurial status: A meta-analytical review. Journal of Applied Psychology, 91(2), 259-271. 